\title{
IMPROVING THE STUDENTS' SPEAKING ABILITY THROUGH ROTATING TRIO EXCHANGE STRATEGY
}

\author{
Meningkatkan Kemampuan Berbicara Siswa Melalui Strategi Rotating Trio \\ Exchange
}

Maharida

English Education Department, Faculty of Teacher Training and Education Muhammadiyah University of Makassar

\begin{abstract}
This research purposed to find out how the improvement of the students' speaking accuracy and fluency through Rotating Trio Exchange Strategy at the eighth year of SMPN 1 Pallangga. This research was a classroom action research (C.A.R) which consisted of two cycles in which every cycle consisted of four meetings. The subject of this research was one of classes with the total of students is 33 students. The instruments were oral test and observation sheet. The research findings of this research indicated the students'speaking ability in terms of accuracy and fluency through Rotating Trio Exchange Strategy was effective and significant in improving the students' speaking ability. It was proved that the findings indicate that the mean score of cycle II was greater than the mean score of cycle I $(7.55>5.84)$ and the mean score of cycle I also was greater than the mean score of D-test $(5.84>4.19)$, it means that Rotating Trio Exchange Strategy improved the students' speaking ability in English. Besides, it is better to use in teaching speaking ability than the conventional strategies because this was also improved the students interest to make them active in learning speaking ability. The conclusion of the research, Rotating Trio Exchange Strategy improved the student improved the student ability in accuracy and fluency.
\end{abstract}

Keywords: speaking, rotating trio exchange

Speaking is the ability that requires the process of communicative competence, pronunciation, intonation, grammar and vocabulary improving. Speaking is the most important skill, since it is one of the abilities to carry out conversation with others, give ideas and change the information with the people are able to know the situation that happen in the world. English language is not only taught and learned, but it is used as a habit.

According to Stevick (1982: 103) speaking refers to the gap between linguistic expertise and teaching methodology. Linguistic expertise concerns with language structure and language content. Teaching speaking is not like listening, reading, and writing. It needs habit formation because it is a real communication. The speaking needs to be practiced as often as possible. It is not like writing and reading but speaking must be practiced directly in full expression. 
Nevertheless, according to Melannie (2012), for the beginner especially the students in junior high school, speaking exercise is difficult to try. The students always get the problem in speaking. The problems are; the first, the students always do the mistakes in grammar and pronounciation aspect. Basically, they only spoke English but they did not pay attention to the sentence structure and correct pronunciation. The second, the students are afraid of making mistake in speaking English. It indicates that the students have restrictive vocabulary. The third, the students are difficult to speak fluently since they are seldom to practice their English language.

The problem above is faced by the students of SMP 1 Pallangga at eighth grade. When the teachers give an oral test, especially, to the eighth grade students, many students achieve low scores. It is about 6.1 mean score and the target score that would be achieved is 7.5. Their score is lower than Standardized Score or Standar Kelulusan Batas Minimal (SKBM). This situation leads the researcher to investigate what actually the students experience while learning speaking English.

From the problems above the researcher applied one of teaching strategy. That was an interesting strategy and it improved the student's speaking ability, namely rotating trio exchange. The strategy was designed to create the students' interest to learn with pleasant method. The core of rotating trio exchange was corporation between groups and shared. Mel (1996) states that rotating trio exchange is a strategy which makes the students enjoy and can decrease worry in learning speaking. It encourages creative thinking. Students can increase their speaking ability by using a new language and being motive students for learning. Rotating Trio Exchange encourages the students' active speaking participation in the classroom, since this strategy contains a rich communication where students must be active.

\section{The Concept of Rotating Trio Exchange}

Darkenwald and Merriam (1982) states that learning through exchange identical by studying to direct themselves (self directed learning) and private learning. The appropriate definition is the student who has studied a particular 
material or skill with another person who wants to be learning source. The principal of Learning exchange model have the similarity with the concept of the other learning model. Learning exchange is learning model that emphasizes on the context of group dynamics as principal in changing the attitude.

According to Mel (1996), rotating trio exchange composes a variety of questions that help students begin discussion of the course content. Use questions with no right or wrong answers. Divide students into trios. Arrange them around the room so that each trio can clearly see a trio to the right and left. Give each trio an opening question (the same for each trio) to discuss. Start with the least challenging question and suggest that each person take a turn answering the question. After a suitable period for discussion, ask the trios to assign 0,1 , or 2 to each of its members. Direct the students with number 1 to rotate one group clockwise, number 2 rotates two trios clockwise, number 0 remains seated since they are the permanent members of a trio site. The result will be entirely new trios. Start a new exchange with a new question. You can rotate trios as many times as you have questions to pose and discussion time to allot. Each time, use the same rotation procedure.

a. The Procedure of Rotating Trio Exchange

1) Compose a variety of questions that help participants begin discussion of the course content.

2) Divide participants into trios. Position the trios in the room so that each trio can clearly see other trios to its right and to its left. (The best configuration of trios is a circle or square.)

3) Give each trio an opening question (the same question for each trio) to discuss. Select the least threatening question you have devised to begin the trio exchange. Suggest that each person in the trio take a turn answering the question.

4) After a suitable period of discussion, ask the trios to assign a 0,1 , or 2 to each of their members. Direct the participants with the number 1 to rotate one trio clockwise and the participants with the number 2 to 
rotate two trios clockwise. Ask the participants with the number 0 to remain seated. They will be permanent members of a trio site. Have them raise their hands high so that rotating participants can find them. The result of each rotation will be entirely new trios.

5) Start each new exchange with a new question. Increase the difficulty or sensitivity of the questions as you proceed.

6) You can rotate trios as many times as you have questions to pose and the discussion time to allot. Use the same rotation procedure each time. For example, in a trio exchange of three rotations, each participant will get to meet six other participants in depth.

b. The Advantages and Disadvantages of Rotating Trio Exchange

a) The Advantages of Rotating Trio Exchange

1) Discussion of controversial topics promotes more sophisticated thinking

2) Learn Faster; Working together, students in study groups can generally learn faster than students working alone. In addition, the students can help your fellow students also when they have difficulties in understanding something that the other students do understand.

3) Get new perspectives; If the students study by yourself, they will always see your material from the same perspective. While this may not be a problem, getting fresh perspectives on a topic can help you learn it more thoroughly. Study groups are the perfect places to find these new perspectives. As the students listen and ask questions, they will soon start noticing a wide variety of different viewpoint on the same idea. This will force them to think more about their position and will, therefore, develop their critical thinking skills while helping they study.

4) Learn new study skills

5) Breaks the monotony; studying by yourself, especially for long periods of time, can become a monotonous activity. However, by joining a study group, the students can break this monotony and learn faster. In 
addition, the auditory factor of study groups can help auditory students who dislike the silence of studying alone.

6) Fill in learning gaps; Study groups provide an excellent opportunity to fill in gaps in the notes. By comparing notes with other students, the students can evaluate the accuracy, fix any errors, and get ideas for better note taking. If the students are a great note taker, the students can help other students who had note taking problems fix their mistakes and learn better techniques.

b) The Disadvantages of rotating trio exchange

1) Students going at different speeds

One of the biggest disadvantages is that grouping students together will almost always form a group in which some students are faster learners than others. The students who need more time to understand the work may feel frustrated at being left behind. Alternately, students who learn faster may feel delayed or held back by having to wait for the ones that learn more slowly.

2) Leadership dynamics

Another disadvantage of rotating trio exchange is that there are certain groups dynamics present in all groups. Some students will always be leaders while others are followers. If one student tries to take over the group and the other students do not feel equally heard or valued, it can make it difficult for work to be done. Instead, the students spend time arguing over who is in charging as opposed to working together toward.

3) Common goal.

4) Differences in pulling weight

Yet another problem that might arise in cooperative learning is the difference in weight pulling. Some students may think that because they are working in a group, they can slack off. Other times, a student may not have the ability to contribute equally to the project. In either case, it can foster resentment in students who have to shoulder more than their fair share of work.

\section{RESEARCH METHODOLOGY}




\section{A. Research Design}

In this research used Class Room Action Research (CAR). Classroom action research consists of four steps namely planning, action, observation, and reflecting. In this research, the classroom action research (CAR) was intended to change the students' performance in speaking skill through Rotating Trio Exchange.

\section{B. Research Instrument}

The instrument used to obtain data concerning the students' achievement on speaking skill. It was speaking tests which use oral test and observation sheet to find out the students' participation during teaching and learning process. The test consisted of questions which were given by every student in the class and automatically they must answer those questions directly by their own purpose. The tests measured the students' achievement in speaking class.

\section{Data Collection}

The method which used in collecting data was observation and speaking test. In these cases, the data took from the source by employing observation and speaking test. Observation was to observe the students' activeness and presented in the teaching and learning process by using observation sheet that check listed by the observer based on their activeness. Meanwhile, the researcher gave oral test to the student in order to know the prior knowledge of the student after taking actions in cycles.

The researcher used rate of score and criteria components were as follows: a. Vocabulary

\begin{tabular}{|c|c|l|}
\hline \hline Classification & Score & \multicolumn{1}{c|}{ Criteria } \\
\hline \hline Excellent & $9.6-10$ & They speak effectively and excellent of using vocabulary \\
\hline Very good & $8.6-9.5$ & They speak effectively and very good of using vocabulary \\
\hline Good & $7.6-8.5$ & They speak effectively and good of using vocabulary \\
\hline Fairly good & $6.6-7.5$ & $\begin{array}{l}\text { They speak sometimes hasty but fairly good of using } \\
\text { vocabulary }\end{array}$ \\
\hline Fair & $5.6-6.5$ & They speak sometimes hasty, fair of using vocabulary \\
\hline Poor & $3.6-5.5$ & $\begin{array}{l}\text { They speak hasty, and more sentences are not appropriate } \\
\text { using vocabulary }\end{array}$ \\
\hline Very poor & $0.0-3.5$ & $\begin{array}{l}\text { They speak very hasty, and more sentences are not } \\
\text { appropriate using vocabulary and little or no } \\
\text { communication }\end{array}$ \\
\hline
\end{tabular}

b. Pronunciation

(Layman 1981) 


\begin{tabular}{|c|l|l|}
\hline Classification & \multicolumn{1}{|c|}{ Score } & \multicolumn{1}{c|}{ Criteria } \\
\hline Excellent & $9.6-10$ & They speak effectively and Excellent of pronunciation \\
\hline Very good & $8.6-9.5$ & They speak effectively and very good of pronunciation \\
\hline Good & $7.6-8.5$ & They speak effectively and good of pronunciation \\
\hline Fairly Good & $6.6-7.5$ & They speak sometimes hasty, but Fairly Good of pronunciation \\
\hline Fair & $5.6-6.5$ & They speak sometimes hasty, fair of pronunciation \\
\hline Poor & $3.6-5.5$ & $\begin{array}{l}\text { They speak hasty, and more sentences are not appropriate in } \\
\text { pronunciation. }\end{array}$ \\
\hline Very Poor & $0.0-3.5$ & $\begin{array}{l}\text { They speak very hasty and more sentences are not appropriate in } \\
\text { pronunciation, and little or no communication. }\end{array}$ \\
\hline
\end{tabular}

(Layman 1981)

1. The Assessment of Speaking Fluency

a. Effectiveness

\begin{tabular}{|c|c|l|}
\hline Classification & Score & \multicolumn{1}{c|}{ Criteria } \\
\hline \hline Excellent & $9.6-10$ & $\begin{array}{l}\text { Their speaking is very understandable and high of } \\
\text { effectiveness. }\end{array}$ \\
\hline Very good & $8.6-9.5$ & $\begin{array}{l}\text { Their speaking is very understandable and very good of } \\
\text { effectiveness }\end{array}$ \\
\hline Good & $7.6-8.5$ & They speak effectively and good of effectiveness \\
\hline Fairly Good & $6.6-7.5$ & They speak sometimes hasty but fairly good of effectiveness \\
\hline Fair & $5.6-6.5$ & \multicolumn{1}{|c|}{ They speak sometimes hasty, fair of effectiveness } \\
\hline Poor & $3.6-5.5$ & They speak hasty and more sentences no effectiveness \\
\hline Very poor & $0.0-3.5$ & $\begin{array}{l}\text { They speak very hasty and more sentences and no } \\
\text { effectiveness. }\end{array}$ \\
\hline
\end{tabular}

B. Data Analysis

(Layman 1981)

The data that get from cycle I and cycle II are analyzed through the following steps:

1. To find out the mean score of the students' test, the researcher used the following formula: $\bar{X}=\frac{\sum X}{N}$

Where: $\quad \begin{array}{rlrl}\bar{X} & =\text { Mean score } & N \quad \text { Number of student } \\ \sum X & =\text { Total score } & & \end{array}$

2. After collecting the data of the students, the researcher classified the score of the students. To classify the students' score, there was seven classifications which were used as follows:
a. $\quad 9.6$ to 10 is classify as excellent
b. $\quad 8.6$ to 9.5 is classify as very good
c. $\quad 7.6$ to 8.5 is classify as good
d. $\quad 6.6$ to 7.5 is classify as fairy good
e. $\quad 5.6$ to 6.5 is classify as fairy 


\section{f. $\quad 3.6$ to 5.5 is classify as poor \\ g. $\quad 0.0$ to 3.5 is classify as very poor}

(Direktorat Pendidikan, 1999)

Based on the categorized above, the researcher knew the score of the student. By classifying the score, the researcher knew the improvement of each student. This score helped the researcher to determine the percentage of students score.

3. To Calculate the percentage of the students' score, percentage formula was used.

\section{Observation}

The observer observed the students' activeness and presented in the teaching and learning process by using observation sheet that check listed by the observer based on their activeness.

\section{Indicator}

Students respond the material very actively

Students respond the material actively

Students respond the material just one or twice

Students just sit down during the activity without doing something

$\begin{array}{cc}\text { The students } & \text { Score } \\ \text { participation } & \\ \text { Very active } & 4 \\ \text { Active } & 3 \\ \text { Fairly Active } & 2 \\ \text { Not Active } & 1\end{array}$

\section{FINDINGS AND DISCUSSION}

\section{A. The Findings}

\section{The Improvement of the Students' Speaking Accuracy}

The application of rotating trio exchange strategy in improving the students' speaking accuracy deals with vocabulary and pronunciation. The improvement of the students' speaking accuracy at the eighth year students' of SMPN 1 Pallangga can be seen clearly in the following table:

Table 1: The Improvement of the Students' Speaking Accuracy

\begin{tabular}{|c|c|c|c|c|c|c|}
\hline \multirow[t]{2}{*}{ Indicators } & \multicolumn{3}{|c|}{ The Student' Score } & \multicolumn{3}{|c|}{ Improvement } \\
\hline & D-Test & Cycle I & Cycle II & $\mathrm{DT} \rightarrow \mathrm{CI}$ & $\mathrm{CI} \rightarrow \mathrm{CII}$ & $\mathrm{DT} \rightarrow \mathrm{CII}$ \\
\hline Vocabulary & 4.13 & 6.15 & 7.80 & 2.02 & 1.65 & 3.67 \\
\hline Pronounciation & 4.25 & 5.53 & 7.85 & 1.28 & 2.32 & 3.6 \\
\hline$\sum X$ & 8.38 & 11.68 & 15.65 & 3.3 & 3.97 & 7.27 \\
\hline $\bar{X}$ & 4.19 & 5.84 & 7.825 & 1.65 & 1.98 & 3.6 \\
\hline
\end{tabular}


The table above indicates that there is significant improvement of the students' speaking accuracy from Diagnostic-Test to cycle I and cycle II (Diagnostic -Test < cycle I < cycle II) which in Diagnostic-Test of the students' mean score achievement in speaking accuracy is 4.19 , after evaluation in cycle I, the students' speaking accuracy becomes 5.84, so the improvement of the students' speaking accuracy achievement from Diagnostic-Test to cycle I is 1.65 .

There is also significant improvement of the students' speaking accuracy from cycle I to cycle II where the students' speaking accuracy in cycle I is 5.84 and in cycle II is 7.825. So the improvement of students' speaking accuracy achievement from cycle I to cycle II is 1.98 .

In the table above also indicates that the indicators of students' speaking accuracy improve significantly in which Diagnostic-Test, the students' vocabulary achievement is 4.13. After evaluation in cycle $\mathrm{I}$, the students' achievement in vocabulary became 6.15 and in cycle II became 7.80 . The students' pronunciation achievement also improve from Diagnostic-test to cycle I is 4.25 to 5.53 and in cycle II is 7.85 .

The table above shows the significant improvement of the students' speaking accuracy through rotating trio exchange strategy in teaching and learning process after taking action in cycle I and cycle II in which the students' improvement in cycle II is the highest and the improvement of students' speaking accuracy from diagnostic - test to cycle II is 3.60 .

To see clearly the significant improvement of the students' speaking accuracy, the following chart is presented:

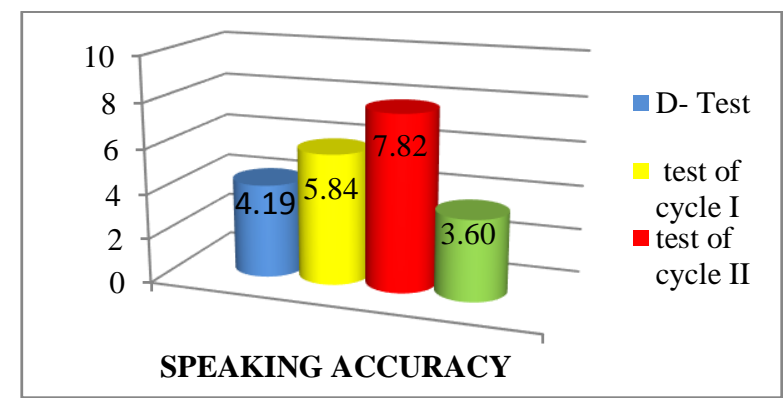

Figure 1: The Improvement of the Students' Speaking Accuracy 
The chart above show the significant improvement of the students' speaking accuracy which in cycle II is higher 7.825 than cycle I (5.84) and Diagnostic -Test (4.19). It also showed that the result of Diagnostic-Test is the lowest mean score achievement. The students' improvement in D- test is categorized as poor. After evaluation in cycle I and cycle II, signticant improvement of the students' speaking accuracy where the result of cycle I is categorized as fair and cycle II categorized as good (Poor Fair Good ).The significant improvement is shown clearly in the chart above, that is 3.60.

\section{The Improvement of the Students' Speaking Fluency}

The application of rotating trio exchange strategy in improving the students' speaking fluency deals with effectiveness. The significant improvement of the students' speaking fluency at the eighth year students' of SMPN 01 Pallangga can be seen clearly in the following table:

Table 2: The improvement of the students' speaking fluency

\begin{tabular}{|l|l|l|l|l|l|l|}
\hline \multirow{2}{*}{ Indicators } & \multicolumn{2}{|l|}{ The Student' Score } & \multicolumn{2}{l|}{ Improvement } \\
\cline { 2 - 8 } & & & & DT $\rightarrow$ CI & CI $\rightarrow$ CII & DT $\rightarrow$ CII \\
\hline Effectiveness & 4.24 & 5.70 & 7.83 & 1.46 & 2.13 & 3.59 \\
\hline$\sum X$ & 4.24 & 5.70 & 7.83 & 1.46 & 2.13 & 3.59 \\
\hline $\bar{X}$ & 4.24 & 5.70 & 7.83 & 1.46 & 2.13 & 3.59 \\
\hline
\end{tabular}

The table above indicates that there is significant improvement of the students' speaking fluency from D-Test to cycle I and cycle II, which in D-Test the students' score improvement in speaking fluency is 4.24. After evaluation in cycle I the students' speaking fluency becomes 5.70, so the improvement of students' speaking fluency from D-Test to cycle I is 1.46 . There is also significant improvement of students speaking fluency from cycle I to cycle II where the students' speaking fluency in cycle I is 5.70 and in cycle II is 7.83. So the significant improvement of students' speaking fluency from cycle I to cycle II is 2.13 .

To see the significant improvement of the students' speaking fluency clearly clearly, a chart is presented as follows: 


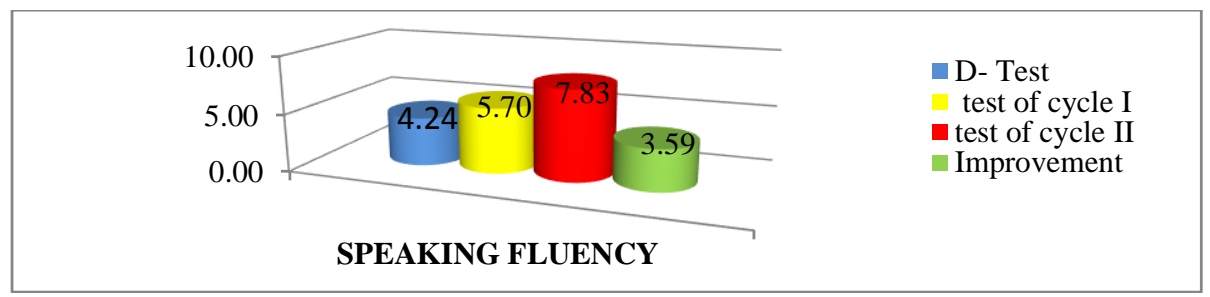

Figure 2: The Improvement of the Students' Speaking Fluency

The chart above shows the significant improvement of the students' speaking fluency in cycle II is higher (7.83) than cycle I (5.70) and D-Test (4.24). It also shows that the result of D-Test was the lowest achievement. (D-Test < Cycle I < Cycle II). After evaluation in cycle I and cycle II, there is significant improvement of the students' speaking fluency that is shown clearly in the chart after taking an action in cycle through rotating trio exchange strategy that is 3.59.

\section{The Improvement of the Students' Speaking Ability}

The application of rotating trio exchange strategy in improving the students' speaking ability deals with speaking accuracy and speaking fluency. The significant improvement of the students' speaking ability that dealing with accuracy and fluency can be seen clearly in the following table:

Table 3: The improvement of the students' speaking ability

\begin{tabular}{|c|c|c|c|c|c|c|}
\hline \multirow[t]{2}{*}{ Indicators } & \multicolumn{3}{|c|}{ The Student' Score } & \multicolumn{3}{|c|}{ Improvement } \\
\hline & D-Test & Cycle I & Cycle II & $\mathrm{DT} \rightarrow \mathrm{CI}$ & $\mathrm{CI} \rightarrow \mathrm{CII}$ & $\mathrm{DT} \rightarrow \mathrm{CII}$ \\
\hline Accuracy & 4.20 & 5.77 & 7.82 & 1.57 & 2.05 & 3.62 \\
\hline Fluency & 4.24 & 5.70 & 7.83 & 1.46 & 2.13 & 3.59 \\
\hline$\sum x$ & 8.44 & 11.47 & 15.65 & 3.03 & 4.18 & 7.21 \\
\hline $\bar{X}$ & 4.22 & 5.74 & 7.825 & 1.5 & 2.09 & 3.60 \\
\hline
\end{tabular}

The table above indicates that there is significant improvement of the students' speaking ability from D-Test to cycle I and cycle II, which in D-Test the students' mean score achievement in speaking ability is 4.22 . It is categorized as poor achievement. After evaluation in cycle I the students' speaking ability becomes 5.74. It categorized as fair. So the significant improvement of students' speaking ability achievement from D-Test to cycle $\mathrm{I}$ is 1.5. There is also significant improvement of students speaking ability from cycle I to cycle II where the students' speaking ability in cycle I is 5.74 and in cycle II is 7.825 . The students' achievement in cycle II is categorized as good, so the significant 
improvement of students' speaking ability achievement from cycle I to cycle II is 2.09 .

The table above proves there is significant improvement of the students' speaking accuracy through rotating trio exchange strategy in teaching and learning process after taking action in cycle I and cycle II where the students' achievement in cycle II was the highest (Cycle II > Cycle I > Diagnostic- test) and the significant improvement of students' speaking ability from diagnostic - test to cycle II is 3.60 .

To see significant improvement of the students' speaking ability clearly, following chart is presented:

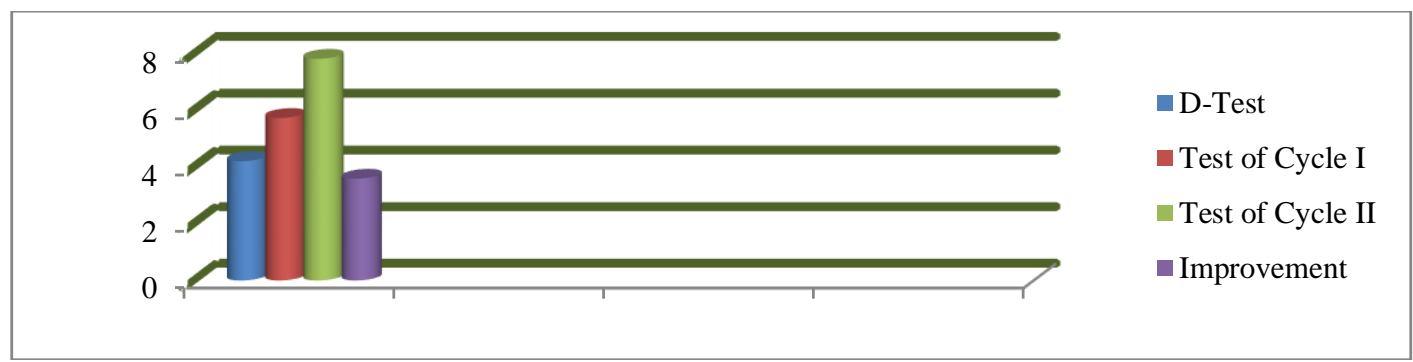

Figure 3: The Improvement of the Students' Speaking Ability

The chart above shows the significant improvement of the students' speaking ability in cycle II is higher (7.825) than cycle I (5.74) and D-Test (4.22). (Cycle II > Cycle I > Diagnostic - Test). It also shows that the result of Diagnostic -Test is the lowest achievement. The students' achievement in Diagnostic test is categorized as poor. After evaluation in cycle I and cycle II, there is significant improvement of the students' speaking ability where the result of cycle $I$ is categorized as fair and cycle II categorized as good (Poor - Fair - Good).The significant improvement is shown clearly in the chart above that is 3.60.

\section{The Result of the Students' Activeness in Teaching and Learning Process}

The result of observation of the students' activeness in teaching and learning process toward the application of rotating trio exchange strategy in improving the students' speaking ability at the eighth year students of SMPN 1 Pallangga in class VIII-8 which is conducted in 2 cycles during 8 meetings is taken by the 
observer through observation sheet. It can be seen clearly through the following table:

Table :4The observation result of the students' activeness in learning process.

\begin{tabular}{|l|c|c|c|c|l|l|}
\hline \multirow{2}{*}{ Cycle } & \multicolumn{3}{|l|}{ Meetings } & \multicolumn{1}{|l|}{ Improvement } \\
\cline { 2 - 5 } & I & II & III & IV & $\begin{array}{l}\text { Average } \\
\text { Score }\end{array}$ & \\
\hline I & $60.6 \%$ & $66.7 \%$ & $75 \%$ & $78.8 \%$ & $70.27 \%$ & $5.45 \%$ \\
\hline II & $75.7 \%$ & $68.2 \%$ & $78 \%$ & $81 \%$ & $75.72 \%$ & \\
\hline
\end{tabular}

The result above was formulated based on the technique of data analysis and the students' scores that were collected through observation sheet. From the table above shows that in cycle I the students' activeness in each meeting improves significantly. It can be seen clearly in table that the students' activeness in the fourth meeting is higher than the first, the second and the third meeting, where the first meeting in cycle I the students' activeness is $60.6 \%$ and it improves to $66.7 \%$ in the second meeting, and then students' activeness in the third meeting is $75 \%$ improves to $78.8 \%$ in the forth meeting, so the average of the students' activeness in cycle I is $70.27 \%$.

In cycle II the improvement of the students' activeness is up and down. Where in the first meeting in cycle II the students' activeness is $75.7 \%$ decrease to $68.2 \%$ in the second meeting and it is lower than the first meeting. It is caused by the discussed topic which is not interesting for the students. In the third meeting in cycle II the students' activeness improves normally to 78\%, and then in the forth meeting the students' activeness improves to $81 \%$. This is caused by the teaching material is really interesting for the students and the teacher give them game when opens the class. So the average of the students' activeness in cycle II is $75.72 \%$. Later, the result is presented in the chart below that show the average of student' activeness in the first cycle and the second cycle. 


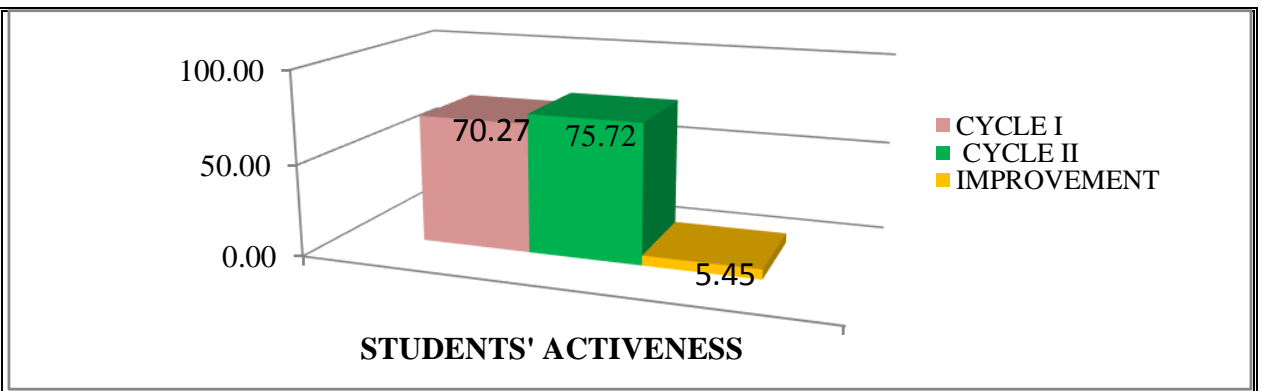

Figure 4: The Improvement of the Students' Activeness

The chart above shows the students' participation as a result of observation in learning speaking through "rotating trio exchange" strategy at the eighth grade students' of SMP Negeri 1 Pallangga. The chart above present the students' situation during teaching and learning process dealing with the students' activeness and presence in teaching and learning speaking ability from cycle I to the cycle II while each cycle consist of fourth meetings. Based on the chart above, there is changing of the students' participation in learning reading comprehension from the first meeting until the eight meeting in cycle I to cycle II.

\section{B. Discussion}

1. The improvement of the students' speaking accuracy dealing with vocabulary and pronunciation.

a. Vocabulary

The application of rotating trio exchange strategy in improving the students' speaking accuracy in terms of vocabulary can be seen the difference by considering the result of the students' Diagnostic Test and the students' achievement after taking action in cycle I and II through the application of rotating trio exchange strategy in teaching and learning process.

Table 5: The Percentage of the Students' Vocabulary in Speaking.

\begin{tabular}{|c|c|c|c|c|c|c|c|c|}
\hline \multirow[t]{3}{*}{ No } & \multirow[t]{3}{*}{ Classification } & \multirow[t]{3}{*}{ Range } & \multirow{2}{*}{\multicolumn{2}{|c|}{$\begin{array}{c}\text { Non RTE } \\
\text { D-Test } \\
\end{array}$}} & \multicolumn{4}{|c|}{ The Application of RTE } \\
\hline & & & & & \multicolumn{2}{|c|}{ Cycle I } & \multicolumn{2}{|c|}{ Cycle II } \\
\hline & & & Freq & $\%$ & Freq & $\%$ & Freq & $\%$ \\
\hline 1 & Excellent & $9.6-10$ & 0 & 0 & 0 & 0 & 0 & 0 \\
\hline 2 & Very good & $8.6-9.5$ & 0 & 0 & 0 & 0 & 0 & 0 \\
\hline 3 & Good & $7.6-8.5$ & 0 & 0 & 0 & 0 & 13 & $39 \%$ \\
\hline 4 & Fairly good & $6.6-7.5$ & 0 & 0 & 8 & $24 \%$ & 20 & $60 \%$ \\
\hline 5 & Fair & $5.6-6.5$ & 2 & $6 \%$ & 11 & $33 \%$ & 0 & 0 \\
\hline 6 & Poor & $3.6-5.5$ & 18 & $54 \%$ & 14 & $42 \%$ & 0 & 0 \\
\hline
\end{tabular}




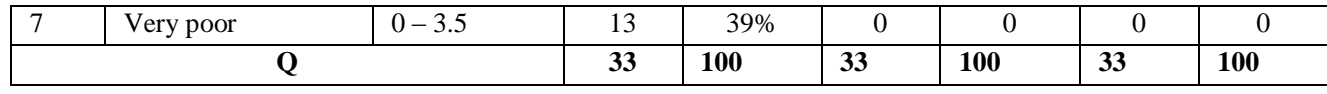

The table above shows that the percentage of the students' vocabulary in speaking Diagnostic Test indicates that 2 students (6\%) get fair, 18 students (54\%) get poor, and 13 students (39\%) get very poor. After taking an action in cycle I by using rotating trio exchange strategy, the percentage of the students' vocabulary is 8 students (24\%) get fairy good, 11 students (33\%) get fair, 14 students $(42 \%)$ get poor and none of the students for the other classification.

In cycle II, the percentage of the students' vocabulary in speaking is 13 students (39\%) get good, 20 students $(60 \%)$ get fairly good, and none of the students for the other classification. The result above also proves that the use of rotating trio exchange strategy is improve significantly of the students' speaking vocabulary where result of Cycle II is higher than cycle I and Diagnostic test (Cycle II $\geq$ Cycle I and Cycle I $\geq$ Diagnostic test). To know the percentage of the students' achievement in vocabulary clearly, following chart is presented:

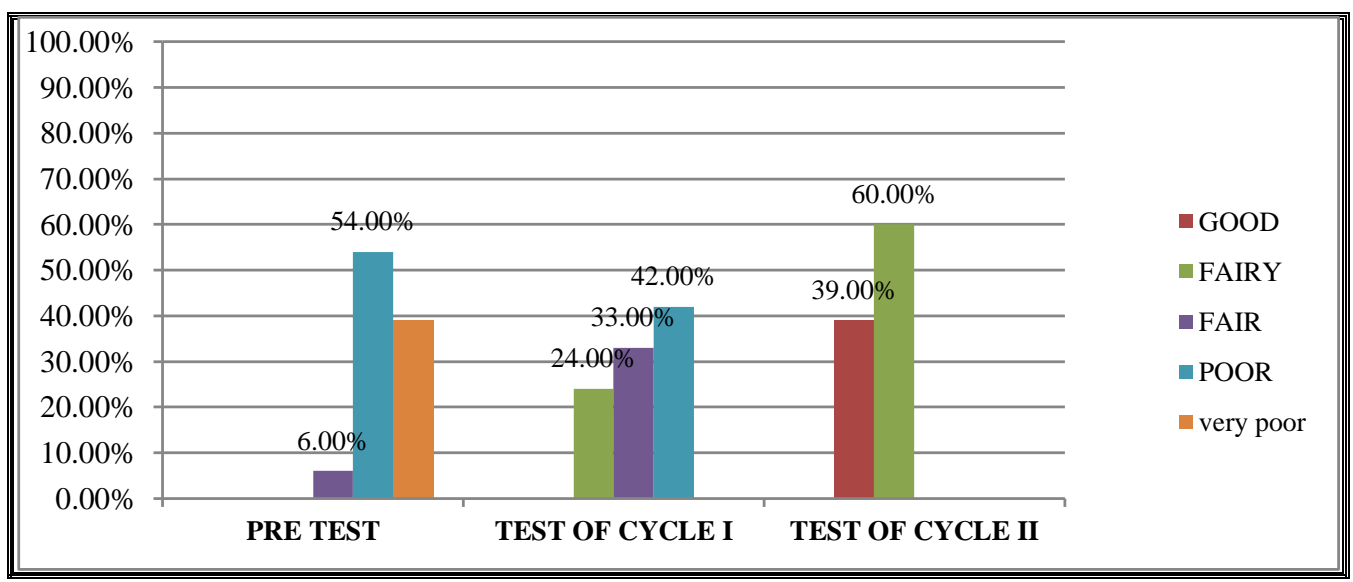

Figure 5: The Improvement of the Students' Speaking Vocabulary

The chart above shows that the result of the students' speaking accuracy in terms of vocabulary. After applying rotating trio exchange strategy in cycle I and cycle II, the result of students' vocabulary achievement improves significantly where Cycle II is higher than D-Test and cycle I. The students' vocabulary achievement in cycle II is $39 \%$ categorized as good and $60 \%$ categorized as fairy good, while in cycle I is lower than cycle II where the students' vocabulary achievement in cycle I was $24 \%$ categorized as fairy good, $33 \%$ categorized as 
fair and $42 \%$ as poor. The D-Test was the lowest where the students' vocabulary achievement was $(6 \%)$ categorized fair, (54\%) poor, and $39 \%$ categorized very poor.

\section{b. Pronunciation}

The application of rotating trio exchange strategy in improving the students' speaking accuracy in terms of pronunciation can be seen the difference by considering the result of the students' Diagnostic- Test and the students' achievement after taking action in cycles through the application of rotating trio exchange strategy in teaching and learning process.

Table 6: The Percentage of the Students' Pronunciation in Speaking.

\begin{tabular}{|c|c|c|c|c|c|c|c|c|}
\hline \multirow[t]{3}{*}{ No } & \multirow[t]{3}{*}{ Classification } & \multirow[t]{3}{*}{ Range } & \multirow{2}{*}{\multicolumn{2}{|c|}{$\begin{array}{c}\text { Non RTE } \\
\text { D - Test }\end{array}$}} & \multicolumn{4}{|c|}{ The Application of RTE } \\
\hline & & & & & \multicolumn{2}{|c|}{ Cycle I } & \multicolumn{2}{|c|}{ Cycle II } \\
\hline & & & Freq & $\%$ & Freq & $\%$ & Freq & $\%$ \\
\hline 1 & Excellent & $9.6-10$ & 0 & 0 & 0 & 0 & 0 & 0 \\
\hline 2 & Very good & $8.6-9.5$ & 0 & 0 & 0 & 0 & 0 & 0 \\
\hline 3 & Good & $7.6-8.5$ & 0 & 0 & 0 & 0 & 18 & $54 \%$ \\
\hline 4 & Fairy good & $6.6-7.5$ & 0 & 0 & 3 & $9 \%$ & 15 & $45 \%$ \\
\hline 5 & Fair & $5.6-6.5$ & 0 & 0 & 8 & $24 \%$ & 0 & 0 \\
\hline 6 & Poor & $3.6-5.5$ & 24 & $72 \%$ & 22 & $66 \%$ & 0 & 0 \\
\hline 7 & Very poor & $0-3.5$ & 9 & $27 \%$ & 0 & 0 & 0 & 0 \\
\hline \multicolumn{3}{|c|}{ Total } & 33 & 100 & 33 & 100 & 33 & 100 \\
\hline
\end{tabular}

The table above shows the percentage of the students' pronunciation achievement in Diagnostic Test indicates that 24 students (72\%) get poor, 9 students $(27 \%)$ get very poor, and none of students for the other classification. After taking action in cycle I by using rotating trio exchange strategy, the percentage of the students' pronunciation achievement improves where 3 students (9\%) get fairy good, 8 students $(24 \%)$ get fair, 22 students $(66 \%)$ get poor and none of the students for the other classification. In cycle II, the percentage of the students' achievement in pronunciation is higher than cycle I where 18 students (54\%) get good, 15 students (45\%) get fairy good, and none of the students for the other classification.

To see the percentage of the significant improvement of the students' pronunciation in speaking accuracy clearly, the following chart is presented: 


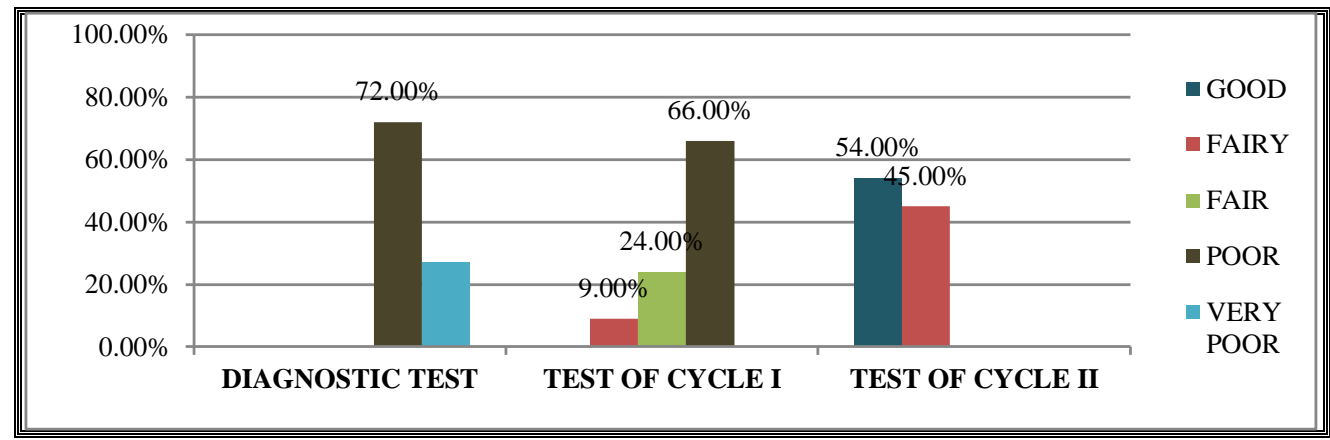

Figure 6: The Improvement of the Students' Speaking Pronunciation

The chart above shows that the result of the students' speaking accuracy in terms of pronunciation. The result of students' pronunciation in cycle II is higher than Diagnostic-Test and cycle I (Cycle II > Cycle I > Diagnostic test) where the students' pronunciation achievement in cycle II is $54 \%$ categorized as good, $45 \%$ categorized as fairy good, while in cycle I is lower than cycle II where the students' pronunciation achievement in cycle I is $9 \%$ categorized as fairy good, $24 \%$ categorized as fair, $66 \%$ categorized as poor, and none of for the other classification. The result of diagnostic test is the lowest than the other where the students' pronunciation achievement is $(72 \%)$ categorized as poor, $27 \%$ as very poor. It indicates that after applying rotating trio exchange strategy in cycle I and cycle II, the result of students' pronunciation achievement improves significantly.

2. The improvement of the students' speaking fluency dealing with effectiveness.

a. Effectiveness

The application of rotating trio exchange strategy in improving the students' speaking fluency in terms of effectiveness can be seen the difference clearly by considering the result of the students' diagnostic test and result of the students' test in cycle I and II (After using rotating trio exchange strategy).

Table 7: The percentage of the students' effectiveness in speaking

\begin{tabular}{|c|c|c|c|c|c|c|c|c|}
\hline \multirow[t]{3}{*}{ No } & \multirow[t]{3}{*}{ Classification } & \multirow[t]{3}{*}{ Range } & \multirow{2}{*}{\multicolumn{2}{|c|}{$\begin{array}{c}\text { Non RTE } \\
\text { D-Test }\end{array}$}} & \multicolumn{4}{|c|}{ The Application of RTE } \\
\hline & & & & & \multicolumn{2}{|c|}{ Cycle I } & \multicolumn{2}{|c|}{ Cycle II } \\
\hline & & & Freq & $\%$ & Freq & $\%$ & freq & $\%$ \\
\hline 1 & Excellent & $9.6-10$ & 0 & 0 & 0 & 0 & 0 & 0 \\
\hline 2 & Very good & $8.6-9.5$ & 0 & 0 & 0 & 0 & 0 & 0 \\
\hline 3 & Good & $7.6-8.5$ & 0 & 0 & 0 & 0 & 18 & $54 \%$ \\
\hline 4 & Fairy good & $6.6-7.5$ & 0 & 0 & 1 & $3 \%$ & 15 & $45 \%$ \\
\hline 5 & Fair & $5.6-6.5$ & 0 & 0 & 15 & $45 \%$ & 0 & 0 \\
\hline
\end{tabular}




\begin{tabular}{|l|l|l|c|c|c|c|c|c|}
\hline 6 & Poor & $3.6-5.5$ & 24 & $72 \%$ & 17 & $51 \%$ & 0 & 0 \\
\hline 7 & Very poor & $0-3.5$ & 9 & $27 \%$ & 0 & 0 & 0 & 0 \\
\hline \multicolumn{2}{|c|}{ Total } & $\mathbf{3 3}$ & $\mathbf{1 0 0}$ & $\mathbf{3 3}$ & $\mathbf{1 0 0}$ & $\mathbf{3 3}$ & $\mathbf{1 0 0}$ \\
\hline
\end{tabular}

The table above shows that the percentage of the students' effectiveness in Diagnostic -Test indicated that 24 students $(72 \%)$ get poor, 9 students $(27 \%)$ get very poor. After taking action in cycle I by using rotating trio exchange strategy, the percentage of the students speaking test in effectiveness is 1 student (3\%) get fairy good, 15 students (45\%) get fair, 17 students (51\%) get poor and none of the students for the other classification. In cycle II, the percentage of the students' speaking test in effectiveness is 18 students (54\%) get good, 15 students (45\%) get fairy good and none of the students for the other classification.

To know the percentage of the students' achievement in effectiveness clearly, following chart is presented:

Figure 7: The Improvement of the Students' Speaking Effectiveness

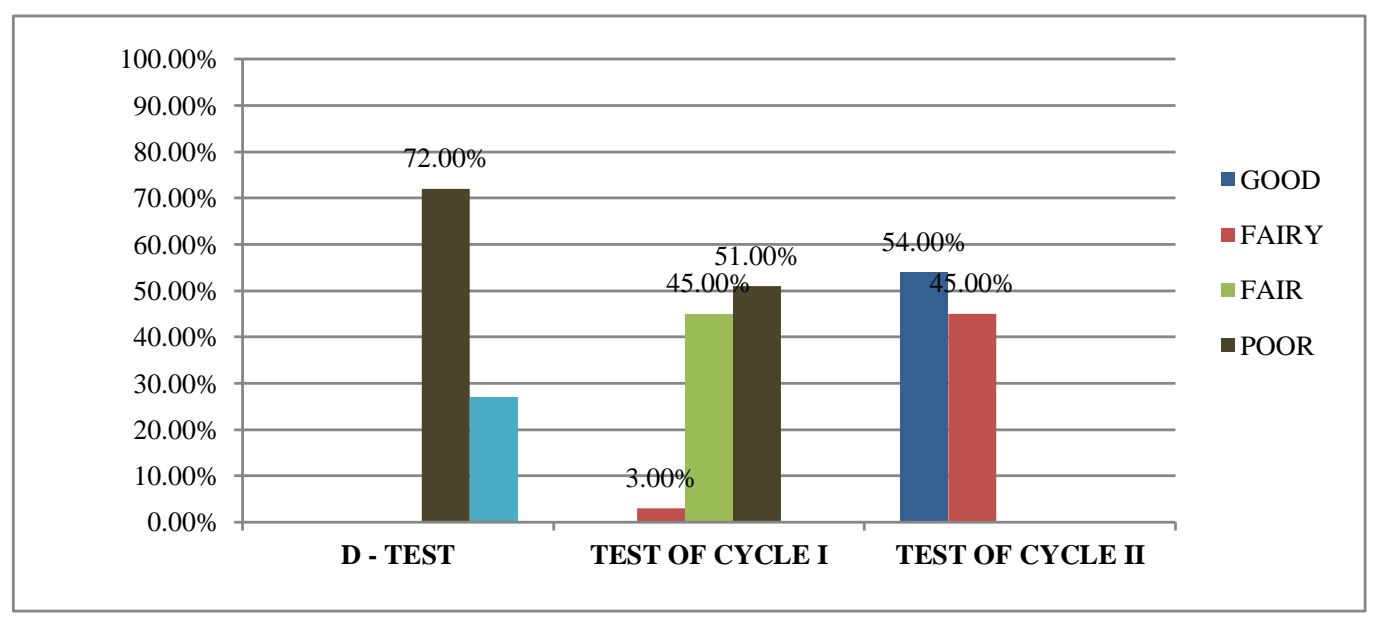

The chart above shows that the result of the students' speaking fluency in terms of effectiveness. After applying rotating trio exchange strategy in cycle II, the result of students' effectiveness is higher than Diagnostic -Test and cycle I (Cycle II > Cycle I > Diagnostic test) which the students' effectiveness achievement in cycle II is $54 \%$ categorized as good and $45 \%$ categorized as fairy good, while in cycle I is lower than cycle II where the students' effectiveness achievement in cycle I is 3\% categorized as fairy good, $45 \%$ categorized as fair, $51 \%$ categorized as poor and non of the other classification. But the result of 
Diagnostic-Test is the lowest where the students' effectiveness achievement is $72 \%$ categorized as poor, $27 \%$ categorized as very poor.

3. The improvement of the students' speaking ability dealing with the students' speaking accuracy and students' speaking fluency.

The result of the data analysis through the speaking test showed that the students' speaking ability in terms of accuracy and fluency improve significantly. It is indicated by the mean score of result of the students' D-Test was 4.22 . It is classified as poor achievement. It is also lower than the mean score of the students' speaking test in cycle I that is 5.74 that is classified as fair and cycle II is 7.825. It is classified as fairy good. Those scores are got from the result test of the students' speaking accuracy and speaking fluency.

a. The students' speaking accuracy at the eighth year students' of SMPN 1 Pallangga, class VIII -8 in 2012/2013 academic year through rotating trio exchange strategy.

The indicator of pronunciation of the students' speaking accuracy in the first cycle has improved from Diagnostic test. The improvement can be seen after testing and observing the students where the improvement of the students' pronunciation is 1.28 and the students' pronunciation mean score was 5.53. It is classified as poor. In cycle II, the students' pronounciation also improves from Cycle I to cycle II where the improvement was 2.32 and the students' mean score was 7.85 that were classified as good classification. The improvement in cycle II is higher than cycle I, so, the research was not continued to the third cycle because the target score had been achieved in cycle II.

In the first cycle, the students' vocabulary in speaking was not bad than the other indicator, like pronunciation. The result of the students' vocabulary can be seen after testing and observing (speaking test of first cycle), whereas the number of students in fairy good score was 24 percent and the mean score achievement was 6.15. It was indicated that there was a significant improvement from diagnostic test to cycle I about 2.02 because the students' mean score in diagnostic test was only 4.13. After testing and observing in 
the second cycle, the student' vocabulary really had a good improvement where the improvement was about 1.65 . The significant improvement is got in cycle II because the teaching speaking material was really suitable for the improvement of the students' vocabulary. Because of the target score had been achieved, the research was not continued to the third cycle.

b. The students' speaking fluency at the eighth year students' of SMPN 1 Pallangga, class VIII -8 in 2012/2013 academic year through rotating trio exchange strategy.

In the first cycle, the students' effectiveness in speaking was not bad. The result of the students' improvement of effectiveness can be seen after testing and observing (speaking test of first cycle), whereas the mean score achievement was 5.70. It was indicated that there was a significant improvement from diagnostic test to cycle I about 1.46 because the students' mean score in diagnostic test was only 4.24. Because of the target was not achieved in the first cycle, researcher worked hard in the second cycle to reach the target and try to evaluate the weakness in the first cycle. After testing and observing in the second cycle, the student' effectiveness really had a good improvement where the improvement was about 2.13. Because of the target score had been achieved, the research was not continued to the third cycle.

\section{CONCLUSION AND SUGGESTION}

\section{A. Conclusions}

Based on the findings and discussion in the previous chapter it can be concluded that the model of learning speaking ability through "Rotating Trio Exchange Strategy" was significantly inmproved the students' speaking ability at the eighth grade students of SMP Negeri 1 Pallangga. This was shown by the following result:

1. Rotating Trio Exchange Strategy improved the students' speaking ability significantly in term of accuracy. It was proved of the students' score in diagnostic test was 4.19, cycle I was 5.84, and cycle II was 7.55 
2. Rotating Trio Exchange Strategy improved the students' speaking ability significantly in term of fluency. It was proved of the students' score in diagnostic test was 4.24, cycle I was 5.70, and cycle II was 7.50.

\section{B. Suggestions}

In relation to the conclusion above, the researcher further states suggestions as follows:

1. There are so many strategies, models or approaches in teaching English especially in speaking that was developed by the expert. Therefore, the teacher should leave the conventional strategies in teaching. As the researcher saw when applying rotating trio exchange strategy, the students enjoyed to work in collaborative. They did not feel boredom because this strategy allowed other strategies work together.

2. The teacher is not the source of knowledge, one of their functions is as the facilitator for their students to get the knowledge. Therefore, the teacher should give th students many opportunities to find the knowledge through teaching them the strategies.

3. For further researchers, it is suggested to conduct further research of rotating trio exchange strategy to find out the effectiveness of this model.

\section{REFERENCES}

Brown, Douglas. 1982. Principle of Language Learning and Teaching. Englewood CLIFFS. New Jersey. Patrice Hall inc.

Byrne, Donn. Teaching Oral English: Longman Handbooks for English Teacher. Singapore: Longman Group, 1986.

Chandran, Reshma. 2011. Language as a tool of communication,(Online), (https://www.classle.net/content-page/language-tool-communication, retrieved on 31 July 2012).

Curtis, Michaele. 2011. The Disadvantages of Using Cooperative Learning,(Online), (http://www.ehow.com/info_10044274_threedisadvantages-using-cooperative learning.html, retrieved on 27 July 2012) 
Cruey, Greg. 2006. The Roles of Students and Teachers, (Online), (http://suite101.com/article/a-philosophy-of-education-part-iv-a4146, retrieved on 31 July 2012)

Darkenwald, G. G. and Merriam, S.B. (1982) Adult Education. Foundations of practice, New York: Harper and Row.

Depdikbud. 1985. Petunjuk Pelaksanaan Proses Belajar Mengajar dan Petunjuk Pelaksanaan Sistem Penilaian. Jakarta:Depdikbud.

Egan, Kathlen, B. Speaking: A Crtical Skill and a Challenge. Calico Journal, (Online), Vol. 16, No. 3, (https://www.calico.org/html/article_615.pdf, retrieved on 28 July 2012)

Elliott, J. (1991), Action Research for Educational Change, Open University Press, Milton Keynes.

Florez \& MaryAnn, C. 1999. Improving Adult English language Learners' Speaking Skills. Eric Digest,(Online), (http://www.ericdigests.org/20003/adult.htm, retrieved on 31 July 2012).

Fromkin, Victoria, and Rodman. 1883. An Introduction to Language Third Edition: Holt, Rinerhart and Winston.

Gay, L. R. 1981. Educational Research Competencies for Analysis and Application. Ohio: Charles E. Merril Publishing. Co.

Hornby, A.S. (1995). Oxford Advance Learners' Dictionary. London: Oxford University Press.

Harmer, Jeremy. 2007. The Practice of English Language Teaching $\left(4^{\text {th }}\right.$ ed.).Essex: Pearson Education.

Johnson, David W., and Roger T. Johnson. 1989. Cooperation and Competition: Theory and Research. Edina, Minn.: Interaction Book Co.

Julian Hermida from Gwyn Mettetal, "The What, Why and How of Classroom Action Research", JoSoTL Vol. 2, Number 1 (2001)

Kayi, Hayriye. Teaching Speaking: Activities to Promote Speaking in a Second Language. The Internet TESL Journal, Vol. XII, No. 11, November 2006.

Klancar, N.I. Developing Speaking Skills in the Young Learner Classroom. The Internet TESL Journal, Vol. XII, No. 11, November 2006. 
Manser, Martin H.1991. Teaching and learning Languages New York: Cambridge University Press.

Marcel. 1978. English Speaking Elements. Last update June, $15^{\text {th }}$ 2008. Available on http//eng.gsu.edu/most.dos/ghtml.

Melannie. 2012. How to Improve your English pronounciation,(Online). (http://www.englishteachermelanie.com/study-tip-how-to-improve-yourenglish-pronunciation/, retrieved on 31 July 2012).

Nate. 2010. The Benefits of Study Group, (Online), (http://www.debtfreescholar.com/2010/02/6-benefits-of-study-groups/, retrieved on 27 July 2012)

Nunan, David . 1993. Designing Task for Communication classroom. New York: Cambridge University press.

Oxford Dictionary. 1996. Oxford Learner's Pocket Dictionary. Oxford University Press. Walton street, New York.

Rivers, W. M.1983. Speaking in Many Tongues (third edition). Cambridge: Cambridge University

Silberman, Mel. (1996). Active Learning: 101 Strategies to Teach Any Subject. Needham Heights, MA: Allyn \& Bacon.

Silberman, Mel. (1998). Active training (2nd ed.). San Francisco, CA: Pfeiffer.

Stevick, Earl W. 1982. Teaching and learning Languages New York: Cambridge University Press.

Thornburry, Scott. 2005. How to Teach Speaking . USA: Longman.

VanBarren, Jennifer. 1999. Public Speaking: Elements of Communication,(Online). （http://www.ehow.com/info_8153338_publicspeaking-elements-communication.html, retrieved on 31 July 2012).

Watkins, Ryan. (2005). 75 e-learning activities: Making online learning interactive.San Francisco, CA: Pfeiffer.

Webster, Noah 1996. Webster's Third New International Dictionary. Gove and Merriam Company Publisher. Springfield, Massachusetts, USA. 
Weinsten, C. E. \& Mayer, R. E. (1986) The Teaching of Learning Strategies. In M.C. Wittrock (Ed.), Handbook of research on teaching. New York: MacMilan. 